\title{
Skriftuurlike perspektiewe op die effek van doop op vergifnis
}

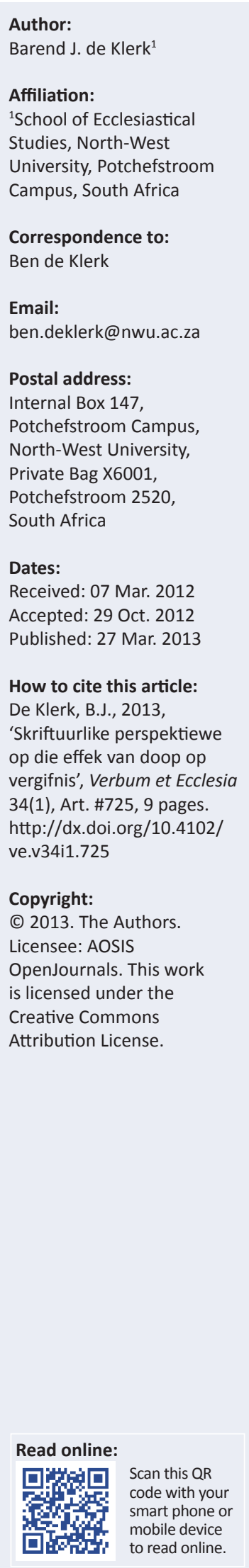

Scriptural perspectives on the effect of baptism on forgiveness. This article focused from a Scriptural perspective on the question of whether baptism can and should have an effect on forgiveness and reconciliation in the South African society. This aspect was examined because in one of the most widely used confessionals of the worldwide church, the Nicene Creed, the following words are found: 'We believe in ... one baptism for the forgiveness of sin'. Another reason for investigating the effect that baptism should have on forgiveness and reconciliation is the connection between God's forgiveness and the calling on the baptised to forgive. The article highlighted the following five key points: God acts in baptism; the Triune God works in baptism; the covenant relationship is expressed in baptism; baptism is a baptism in Christ's death and resurrection; God's forgiveness and reconciliation in baptism call the baptised to forgive.

\section{Inleiding}

Die erediens, veral ook met die doop as liturgiese handeling daarin, verseker gelowiges voortdurend van hul identiteit as huisgesin van God:

It is the primary location where a collective identity is assigned to them, where they learn to know who they are and Whose they are, and that they do not belong to themselves. (Calvin 1960:Institution III.7.1)

Vanuit die erediens van die gemeente beweeg hierdie huisgesin van God in die liturgie van die lewe om God se heerskappy te verkondig. Die erediens besit, deur die werking van die Heilige Gees, die inherente krag om die gedoopte uit te stuur om God se roeping tot vergifnis en versoening in die samelewing uit te leef (Mouton 2001:124).

Die doop het in die afgelope 30 plus jaar hernude belangstelling in teologiese kringe wakker gemaak. Dit het die geleentheid geskep om die teologie van die doop gesamentlik te herontdek en vars te verstaan. In ekumeniese kringe was daar onlangs belangwekkende diskussies oor die doop en die dooppraktyk. Westerfield Tucker $(2011: 1,2)$ skryf byvoorbeeld:

The signing of the Joint declaration on the doctrine of Justification in 1999 by the Pontifical Council for promoting Christian Unity and the Lutheran World Federation - and the World Methodist Council's adoption of the document in 2006 - came about in part of the WCC's earlier work with the BEM (Baptism, Eucharist and ministry) in 1982. Two important ecumenical documents stand directly in lineage of BEM: the 2005 study on the 'Ecclesiological and ecumenical implications of a common Baptism' by the Joint Working Group between the WCC and the Roman Catholic Church; and the soon to be published study text 'One baptism: Towards mutual recognition' approved in 2010 by the World Council's Standing Commission on Faith and Order after more than a decade of development. Two more ecumenical statements related to baptism have received ecclesiastical approvals. A multilateral dialogue between the Roman Catholic church and four Reformed denominations in the USA. The text of 2007 is entitled 'These living waters: Common agreement on mutual recognition of baptism'. In 2011 the World Methodist Council endorsed the text 'Encountering Christ the Saviour: Church and sacrament', produced by the Methodist-Roman Catholic International Commission in which the second chapter examines the subject of 'Baptism: Participation in Christ death and resurrection'. (bl. 2.)

Ook in reformatoriese kringe het die leer van die doop nuwe prominensie gekry. Die vraag is wat die doop doen en hoe God in die doop werksaam is. 'The issue of baptismal efficacy has been pointedly and repeatedly raised in recent years' (Evans 2005:74). Ook in Suid-Afrika word lewendige debatte gevoer oor die effek wat die doop op die handelinge van gelowiges behoort te hê. Dit het veral ter sprake gekom in die debat oor die sogenaamde tweede doop, oftewel die 'bekeringsdoop' of die 'belydenisdoop'. Die argument wat ten gunste daarvan aangevoer word, is dat lidmate nie hul eerste doop wil vervang nie, maar simbolies wil aandui en getuig van hul bekering of die herbevestiging van hul geloof deur 'n tweede doop te ondergaan (De Villiers 2004:3; vgl. Beeld 11 Februarie 2003:11). Kan die afleiding moontlik gemaak word dat die eerste doop by hierdie persone nie die gewenste effek gehad het nie? 
In hierdie artikel word vanuit Skrifperspektief slegs op een aspek gefokus, naamlik of die doop 'n effek kan en behoort te hê op vergifnis en versoening in die Suid-Afrikaanse samelewing. Hierdie aspek word geneem omdat die volgende in een van die wêreldwye kerk se mees algemene belydenisskrifte, die Geloofsbelydenis van Nicea, voorkom: 'Ons glo aan ... een doop tot vergifnis van sonde'. Die oorspronklike bewoording word nie 'as vergifnis van sonde' vertaal nie, maar 'TOT vergifnis'. Met 'tot' word aangedui (Odendaal \& Gouws 2005:1194): 'lei tot, rigting aandui, ter aanduiding van'. Dit gaan daaroor dat die doop heenwys na die vergifnis van sonde, en ook dat dit 'n belofte inhou van vergifnis van sonde (Vorster 2011:46). Die betekenis van hierdie frase 'een doop tot vergifnis van sonde' het van groter belang geword in die lig van die intenser belangstelling in die doop, veral in ekumeniese debatte. 'Yet it is a phrase that very rarely attracts more than passing attention. I have yet to find a single extended examination of it' (Wright 1989:281). Wright sê die konteks waarin die frase gebruik is, is deurslaggewend. Wat is die historiese konteks waarin hierdie frase in die Geloofsbelydenis van Nicea in $325 \mathrm{nC}$ ontstaan het? Cyrillus van Jerusalem verduidelik in sy Pro Chatechesis:

A person cannot be baptized a second or third time. Otherwise, he could say 'I failed once; the second time I will succeed.' Fail once and there is no putting it right. For there is one Lord, one faith, one baptism. It is only heretics who are re-baptized, and that because the first (baptism) was no baptism. (vertaal deur Wright 1989:284)

'n Verdere rede waarom dit nodig is om te kyk na die effek wat die doop op vergifnis en versoening behoort te hê, is die verband tussen God se vergifnis en die roeping van die gedoopte om te vergewe. God het die doop in Christus, deur die Gees, ingestel as teken en seël van die vergewing van sonde (HK vr. \& ant. 69 en 70). In die Ons Vader-gebed waarin Christus sy kerk leer bid, is die vyfde bede: 'Vergeef ons ons skulde, soos ons ook ons skuldenaars vergewe'. Op so ' $n$ manier word die vergewing van eie sonde verbind aan die roeping om ander te vergewe en só versoening te bedien.

Dit laat die vraag ontstaan of gedooptes hierdie effek van die doop, naamlik vergewing van ander en die gepaardgaande versoening met medemense, genoegsaam in die praktyk van die Suid-Afrikaanse samelewing laat posvat. Hoe lyk die werklikheid waarin die gedooptes in Suid-Afrika lewe? Die oorgang na 'n demokrasie in 1994 het vreedsaam verloop en hierdie nuwe samelewing is in die Mandela-era selfs as die reënboognasie bestempel. Die Waarheid- en Versoeningskommissie het belangrike werk gedoen om die pyn wat die verdeeldheid en vyandigheid in die verlede veroorsaak het, in die ope te bring. Vergewing het plaasgevind en amnestie kon aan 'n verskeidenheid mense toegestaan word. Na byna twee dekades van demokrasie is dit'n ernstige vraag of die metafoor van die reënboog nog gebruik kan word. Die bewoners van Suid-Afrika is steeds veelkleurig, maar of hulle iets van die eenheid van die reënboog vertoon, is te betwyfel. Hofsake waarin rassespanning onderliggend is, soos oor onder andere haatspraak, kom meermale voor.
Gedooptes leef in hierdie samelewing. Volgens Statistiek SA 2004 het $79.8 \%$ van die bevolking in Suid-Afrika aangedui dat hulle Christene is. Dit skyn asof selfs hierdie oorweldigende meerderheid nie 'n dinamiese invloed oor vergewing en versoening in die Suid-Afrikaanse samelewing kan uitoefen nie. Wat sou die probleem wees dat hierdie groot persentasie gedooptes vergewing en versoening nie in 'n groter mate laat realiseer nie?

Hierdie ondersoek is beperk tot die vraag: Hoe kan skriftuurlike perspektiewe op die doop dien as maatstawwe om die effek van die doop op vergifnis en versoening te bepaal? ${ }^{1}$ In navorsing in Praktiese Teologie is die bepaling van skriftuurlike norme vir verdere empiriese en strategiese ondersoeke van groot belang (Osmer 2008:4). Praktiese teologie is immers teologie in die ware sin van die woord. Al sou hierdie ondersoek raakpunte met die Nuwe-Testamentiese en Dogmatiese wetenskappe hê, is skriftuurlike perspektiewe op die doop die basis vir die beoordeling van wat empiries oor die stand van doop en vergifnis in die Suid-Afrikaanse samelewing vasgestel kan word en wat as strategie vir verandering voorgestel kan word (vgl. Heitink 1999:178 e.v.). Die metode wat gevolg word, is 'n literatuurstudie van materiaal uit bogenoemde wetenskappe.

Die vyf hoofpunte wat bespreek word, is afleidings wat voorlopig uit die Skrif oor die doop ${ }^{2}$ gemaak is, sonder om daarmee te kenne te gee dat dit ' $n$ volledige lys is:

- God handel in die doop.

- God Drie-enig werk in die doop.

- Die verbondsverhouding word in die doop uitgedruk.

- Die doop is ' $n$ doop in Christus se dood en opstanding.

- God se vergifnis en versoening in die doop roep die gedoopte om te vergewe.

\section{God handel in die doop}

In die doop word nie beseël wat ons is of doen nie, maar wat God belowe (H.K. Sondag 25). By die doop is die klem op die handelinge van God in Christus, op die genade wat Hy ons skenk en op die vernuwing wat die Heilige Gees in ons bewerk. God is die handelende onderwerp in die doop (Immink 2011:170). Thompsett (2004) stel dit só:

The theological emphasis in baptism is based on God's action, expresses God's hopeful interest in humanity, and reveals God's generosity in creation. Baptism is not simply or only an individual decision; it is primarily about God acting and the community of faith responding. It is God's doing that calls forth our responsiveness. Baptism is an expression of God's hope for a people: created, chosen, and adopted anew as God's own. (bl. 10)

Die doop roep op tot 'n nuwe lewe, maar is nie gebaseer op menslike respons nie. Dit is gebaseer op God se vergewende, versoenende en verlossende werk in Christus. Daaruit en in daardie volgorde word gepraat van menslike reaksie daarop.

1.In'n opvolgartikel sal hierdie maatstawwe gebruik word om 'n empiriese ondersoek te loods.

2.Weens die fokus van die artikel word die sogenaamde klein- en grootdoop nie bespreek nie. 
Dat God handel in die doop blyk duidelik uit die instelling van die Christelike doop in Matteus 28:19. Omdat die doop Jesus se opdrag is, is dit van die begin van die Christelike kerk algemeen aanvaar en bedien. 'Maak my dissipels deur hulle te doop in die Naam van die Vader en die Seun en die Heilige Gees en deur hulle te leer om alles te onderhou' (Mat 28:19-20). Die 'doop' en die 'onderhou' van alles bepaal twee kante van dissipelskap. Die 'doop' vorm die goddelike kant en die 'leer onderhou' die menslike kant. In die doop stel God mense onder sy seggenskap op grond van die soenverdienste van Jesus. In die doop kom van God se kant wat ons nodig het vir die belewing van dissipelskap. Wanneer ons gehoorsaam is deur te onderhou wat Hy geleer het, kom ons van die mens se kant tot die belewing van dissipelskap. Die 'doop' gee die lyn wat van God se kant na ons loop en die 'leer onderhou' laat die lyn weer van ons kant na God teruggaan (Versteeg 1983:39). 'n Doop wat in gebreke bly om prakties te reageer op die lering van Jesus, is betekenisloos. Aan die ander kant staan die onderhouding van Jesus se lering nooit op sy eie nie, want dit is gebaseer op God se gawe in die doop.

Die sendingbevel word ook in Markus 16:16 gegee. Daar word 'geloof' aan 'doop' verbind. Sowel 'geloof' as 'doop' word verbind aan die 'prediking van die evangelie'. Die geloof is die aanvaarding van die mens se kant van die prediking en die doop is die bevestiging van God se kant van die prediking. Waar die prediking van die evangelie kom, mag 'n mens in geloof op die prediking antwoord en wil God die prediking onderstreep deur die doop. Die doop word ook hier nie die bevestiging van iets wat die mens gedoen het nie, maar is die bevestiging van die handeling van God (Versteeg 1983:41).

Wanneer hierdie skriftuurlike perspektief van God wat handel in die doop, van God wat met die doop sy beloftes beseël, nie ten volle onderskei word nie, kan die effek wat die doop op menslike handelinge het, onderbeklemtoon word. Die vraag kan gevra word of die dooppraktyk wat menslike handelinge oorbeklemtoon, nie na deformasie neig nie. Die klem in die doop val dan op die horisontale gebeure, byvoorbeeld op die naamgewing van die gedoopte of op die doop as 'n bloot sosiaal familiale aangeleentheid. Menslike handelinge is tog, vanuit reformatoriese hoek gesien, geanker in goddelike handelinge. God se handeling in die doop verseker die gedoopte se vergifnis en versoening, en so kan gedooptes agente word van vergewing en versoening in die konteks waarin hulle lewe.

\section{God Drie-enig werk in die doop}

Doop $^{3}$ in die Naam van die Vader, Seun en Heilige Gees (Mat 28:19) simboliseer, bevestig en vier die eenwees van gedooptes met die Trinitariese God (Koopman 2005:449). In teenstelling met die doop van Johannes en die doop wat

3.Die woord in die Nuwe Testament vir doop is $\beta \alpha \pi \tau$ '́ $\varepsilon$ ev wat ontwikkel het uit $\beta \alpha \pi \tau \varepsilon v^{2}$ $\beta \alpha \pi \tau i$ ¿glv is allereers soos $\beta \alpha \pi \tau \varepsilon i v$ te vertaal met 'indompel' of 'onderdompel'.

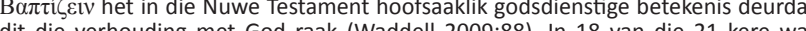
dit die verhouding met God rak (Waddel 2009:88). In 18 van die 21 kere wat $\beta \alpha \pi \tau i \zeta$ \&ıv byvoorbeeld in Handelinge en in die Nuwe-Testamentiese briewe gebruik word, dui dit hoofsaaklik op die doop wat Jesus as opdrag net voor sy hemelvaart gee (Krentz 2006:34; vgl. Hiebert 1992:743) die dissipels aan die begin van Jesus se optrede bedien het, is die doop wat Jesus instel, 'n doop in Christus (Campbell 1996:193). Die doop van Johannes en die doop van Jesus deur Johannes, asook die doop deur sy dissipels was geen koninkryksdoop nie. 'Jesus' baptism in Matthew 28 did not prepare for the new age; it inaugurated it - when linked with the preaching of Jesus' death and resurrection' (Doriani 2003: 39). Spesifiek van dié doop in die Nuwe Testament is dat dit bedien word 'in die Naam van Jesus' (vgl. Hd 8:16). 'n Uitbreiding hiervan kom voor in Matteus 28:19 waar die opdrag van Jesus is om te doop 'in die Naam van die Vader, en die Seun en die Heilige Gees'. Die agtergrond waarteen die uitdrukking 'doop in die naam van' verstaan moet word, kom uit die Ou Testament (Koopman 2005:449). In die besonder moet gedink word aan die seggenskap wat iemand kon uitoefen wanneer sy naam oor iemand anders of oor iets uitgeroep is (vgl. 2 Sam 12:28). In die skrywer se klag in Jesaja 63:19 is daar ' $n$ duidelike parallel tussen die heerskappy van God en die uitroep van die Naam van God. God heers oor hulle oor wie sy Naam uitgeroep is (Goldingay 2001:360). Wanneer iemand gedoop word in die Naam van Jesus, laat Jesus sy seggenskap deur die doop geld oor die lewe van daardie persoon. Net so geld dit dat iemand wat in die Naam van die Drie-enige God gedoop is, onder die seggenskap van daardie God staan.

Die gebruik van die voorsetsel દic vestig die aandag daarop dat die Nuwe Testament nie op doop met of in water fokus nie, maar op die doop in of tot 'n persoon (Pretorius 2003:166). Ridderbos (1987) skryf:

The words 'baptize in' (literally'into') the name of the Father Son and the Holy Spirit mean that the subject of baptism is brought into fellowship with and under authority of Him in whose name he is baptized. (bl. 554)

Die woord 'naam' (ővo $\mu$ ) word meestal in die Bybel figuurlik gebruik om die persoon of wese self aan te dui (Louw \& Nida 1996 [9.19]). In Matteus 28:19 word die dopeling dus verbind aan die wese van die Drie-enige God en sy mag. 'Ovo $\mu \alpha$ in Matteus 28:19 het die dieper betekenis van mag, heerlikheid, majesteit, luister, want Jesus het, ná sy verhoging, 'n Naam bo alle name ontvang (Fil 2:9). Wanneer iemand in die naam van 'n persoon gedoop word, word hy onder sy mag en heerskappy gebring. Die doop in die naam van die Vader beteken dat diegene wat die merk van die verbond of van die Koninkryk ontvang het, onder sy vaderlike, koninklike sorg staan. Die doop in die Naam van die Seun, wat Here en Koning is, kan dus as 'n regeringsverandering omskryf word. Dit wat in die doop beteken en verseël word, bevry die dopeling van die slawerny van die sonde en dood en stel hom onder 'n nuwe Koning, onder wie hy vry is om 'n nuwe lewe te lei (Floor 1983:29). Deur die doop in die Naam van die Heilige Gees word die dopeling onder die gesag, die regering, van die Heilige Gees gebring. Die Gees is by magte om die hart van die dopeling te verander en te vernuwe (De Klerk 2011:378). Elkeen wat gedoop is, of hy dit aanvaar of nie, staan onder die gesag van die Drie-enige God. Dit is in die doop onmiskenbaar bevestig. Om egter die nuwe gesag te erken, vra 'n radikale lewensverandering, 'n nuwe geboorte. Dit is die werk van die Heilige Gees. 
In Handelinge en die Briewe word meestal van die 'doop in die Naam van Jesus', of 'doop in Jesus' gepraat. Handelinge 2:38 wil ook sê dat die doop mag plaasvind in die Naam van Jesus Christus, dit wil sê op grond van die openbaring van die persoon van Jesus, omdat die openbaring tot stand gekom het in die werk wat Hy volbring het (Versteeg 1983:45). Die doop is nie gebaseer op menslike bekering of menslike berou nie, maar alleen en uitsluitend op die Naam van Jesus ${ }^{4}$. Die doop gaan ook nie net oor verlossing en reiniging in Jesus en die aanvaarding van die Vader se beloftes nie. Dit dui ook op die begin én voortsetting van die werk van die Seun van God deur sy Gees. Die reinigende werk en die inwonende krag van die Heilige Gees word tematies in die doopformule in Matteus 28 aangedui (Pretorius 2003:169). Nolland (1999) stel dit só:

The focus now is on what has been achieved in the ministry of Jesus: he has fulfilled the role of Son of God and acted out of and made present the power of the Spirit of God. Though we find ourselves at a point of significant achievement, his work is not finished. He will be with those who will from now on act in His name. (bl. 79)

In die Trinitariese struktuur van die sewe keer 'één' in Efesiërs 4:4-6 kom die doop ook voor. In hierdie verse neem die Gees, Christus en die Vader die sentrale plek in. Die doop word in die reeks Christus, geloof: doop eerstens verbind aan Christus en aan geloof. Tog vorm die sewe heilsweldade één geheel en kan hulle nie los van mekaar gemaak word nie. Die doop staan dus ook hier duidelik in 'n Trinitariese struktuur. Cross (1999) voer aan:

It is important to note that baptism is not included within the legitimate diversity, but is, evidently, one of the foundations of the church's unity on which the diversity is grounded. (bl. 182)

Ook in Titus 3:5 is die Trinitariese struktuur in die uitspraak oor die doop as bad van die wedergeboorte merkbaar. Mawhinney (1987) wys daarop:

In Tit 3:5 Paul reminded Titus that God saved us through the

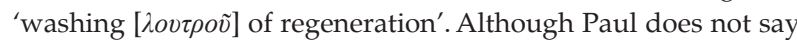
'through the baptism' the water allusion is clear enough. (bl. 47)

Agter die doop staan God in sy ontferming. Daar sou nie van die doop sprake kon wees as God nie in sy ontferming redding geskenk het nie. Die doop plaas ons verder in verhouding met die verlossingsgebeure in Christus, want sy verlossingswerk is die veronderstelling van die doop. Die doop vind ten slotte ook sy vervulling in die werk van die Gees. Die doop wil voortdurend as sakramentele werklikheid die nuwe lewenswerklikheid, wat die Gees geskenk het, laat blyk in die lewe van die gedoopte.

Justinus se geskrifte in die eerste eeue van die kerk se bestaan lewer ook bewys van die Trinitariese konteks waarin hy die doop plaas. Briggman (2009) skryf:

4.Die beste wyse waarop die uitdrukking 'in die Naam van Jesus' verstaan kan word word deur Paulus in 1 Korintiërs 10:2 aangedui. Hy praat daar van die Israeliete wat gedoop is 'in Moses', toe hulle na die uittog uit Egipte deur die Rooi See getrek het gedoop is 'in Moses, toe hulle na die uittog uit Egipte deur die Rooi See getrek het. 'n Letterlike verplasing van die Israeliete in Moses is nie hier ter sprake nie (Cross 1999:185). Paulus bedoel dat die Israeliete deur die deurtog deur die Rooi See 'n doop ontvang het wat hulle aan Moses verbind het (Sparks 2006:659). Synde in Moses gedoop, was die Israeliete op Moses aangewese en staan hulle onder die gesag van Moses. Die uitdrukking 'doop in Christus' verwys daarna dat iemand deu die doop verbind word aan Christus, sodat die gedoopte voortaan in elke opsig op Christus aangewese is en in alle opsigte onder die seggenskap (gesag) van Christus staan (Doriani 2003:40).
... 1 Apol 61, 3 \& 10-13 reveal that early Baptismal ceremonies involved'a washing in water in the name of God, the Father and Ruler of the universe, and of our savior, Jesus Christ, and of the Holy Spirit'. ${ }^{5}$ (bl. 111)

Hoe kan die reformatoriese beskouing van die doop in die Naam van die Drie-enige God meewerk om verandering te bring? Die Drie-enige God het nie sy skepping verlaat nie, maar is steeds getrou as Vader, Seun en Heilige Gees herskeppend teenwoordig in die konkrete werklikheid waarin ons daagliks leef. Vanuit die sekerheid van die Trinitariese werksaamheid in die doop moet afgelei word dat die gedoopte geplaas is onder die seggenskap en sorg van die Vader, die Seun met sy Koningsheerskappy en die Gees met sy begeleiding in die nuwe lewe. Die doop het dus nie net 'n individualistiese, soteriologiese, geestelike betekenis nie; dit het ook betekenis vir die omvattende Koninkryk van God. God plaas die gedoopte deur sy doop in die volle lewe, ook in die kerklike en maatskaplike sfere. Die feit dat die Drieenige God werksaam is in die doop roep die gedoopte op tot reaksie waar ook al Christus as die Koning sy heerskappy uitoefen, ook deur vergifnis en versoening.

\section{Die verbondsverhouding word in die doop uitgedruk}

Die doop is die teken en seël van die Nuwe Verbond. Die God van die verbond het die aard en struktuur van die verbond bepaal. God neem uit vrye wil ouers en kinders in sy verbond op. Hy sluit 'n monopleuriese verbond, want agter die verbond lê God se vrye keuse, sy vrye genade, sy beskikking oor gelowiges en hul nageslag. Nêrens word in die Nuwe Testament aangedui dat die Nuwe Verbond in hierdie opsig anders is as die Ou Verbond nie (Voorberg 2007:336). Mawhinney (1987) sluit hierby aan:

It is widely accepted that when baptism is said to be the sign and seal of the covenant, God is understood to be the covenant King and the Christian is understood to be the covenant servant. (bl. 40)

By die doop word genoem dat God 'n ewige verbond van genade met ons oprig. Dit is 'n ewige verbond omdat die seëninge wat dit omvat, ewige waarde het. Die verbond is nie net' $n$ saak van tyd nie, maar van ewigheid. Ver bo alles wat die tyd bied, gaan die seëninge van die verbond van genade. Dit gaan met gedooptes deur die tyd na die ewigheid. Die seëninge wat in die doop gegee word, is nou reeds, te midde van al die sorge van die tyd, 'n teken van ewige heerlikheid.

Die Here bedien die doop as teken van die afwassing van die sonde aan die dopeling en so word die intrede van die nuwe lid van die verbond persoonlik bevestig. Die gedooptes moet die beloftes van die verbond elk persoonlik deur die geloof toeëien, want hulle is alleen deur die geloof geregverdig voor God. As sodanig is die doop die basis vir die opdrag tot 'n gelowige lewe en het die verbond in sy uitwerking 'n dupleuriese karakter (Voorberg 2007:346). Die

5.1 Apol 61,3: Aanhalings uit Justinus is geneem uit Miroslav Marcovich se lustin Martyris Apologiae pro Christianis (Patristische Texte und Studien 38; Berlin: de Martyris Apologiae pro Christianis (Patristische Texte und Studien 38; Berlin: de
Gruyter 1994), en lustini Martyris Dialogus cum Tryphone (Patristische Texte und Studien 47; Berlin: de Gruyter 1997). 
gedoopte ontvang die beloftes van die verbond wat met die doop gegee word: vergewing van sonde, die Heilige Gees en heiliging. Calvyn beskryf die beloftes só: 'It is a token of cleansing or forgiveness, of dying and being raised with Christ, and of our union with Christ' (Calvin 1960:IV 14.1). Die OuTestamentiese verbondsbelofte is van toepassing op die belofte wat in die doop gegee word: 'Ek sal vir julle 'n God wees en julle sal vir my'n volk wees.' Calvyn stel dit duidelik dat die genadegawes wat objektief in die doop aangebied word, subjektief toegeëien moet word deur die geloof. Evans (2008:78) konstateer: 'This dialectic of offer and reception is foundational for a proper understanding of Calvin's doctrine of baptism.'

Calvyn beklemtoon dat die gedooptes net soveel van die beloftes kan verkry as die mate wat hulle dit in die geloof toeëien: 'If we lack faith, this will be evidence of our ungratefulness, which renders us chargeable before God, because we have not believed the promise given there' (Calvin 1960:IV 15.15). Die doop is ook die teken van die eskatologiese oordeel, om finaal onder die oordeel van die God van die verbond te kom. Om hierdie diep dinamiek van die verbond tot uitdrukking te bring, het God die teken en seël van die verbond, die doop, ingestel. Aldus Ferguson (2009):

Baptism is not efficacious in an ex opere operato fashion. Yet it is not a 'bare' sign, for it communicates to faith or to unbelief that it symbolizes - covenant blessings to covenant faith, covenant curses to covenant disobedience. (bl. 99)

Die doop roep tot geloof, bekering en seën. Wie die genade (en die Christus) verwerp, bly onder die goddelike oordeel en vervloeking. Soos Calvyn dit stel: 'The promise no less threatens wrath to unbelievers than offers grace to believers' (Calvin 1960:IV.14.14).

Die doop eis daarom 'n antwoord, 'n respons op die inisiërende liefde van God. Die doop roep op tot 'n lewenslange verbondsverhouding met God. Die teologiese basis vir 'nlewenslange lewe in ooreenstemming met die eise van die doop is gegrond op die verwagte hoop wat God ons belowe, uitgedruk in 'n soeke na God se heerskappy en wat weer neerslag vind in daaglikse lewe van konstante, lewende hoop (Thompsett 2004:9). Dit vra 'n verbintenis tot lewenslange geloofsvorming deur aanbidding, gebed, Bybelstudie, ' $n$ lewe in die geloofsgemeenskap en oefening in goeie werke, wat ook vergewing en versoening insluit. Deur die werking van die Heilige Gees kan God in, met en deur die gedoopte in die samelewing handel om die prosesse van vergewing en versoening te bevorder.

Die monopleuriese en dupleuriese karakter van die verbond stel die gedoopte in 'n verhouding met God van slaaf tot Koning. Die beloftes van die ewige verbond, wat die gedooptes in geloof toeëien, bring hulle in beweging om die eise van die verbond te gehoorsaam. Die doop roep tot geloof en bekering en ' $n$ nuwe lewe in ooreenstemming met die beloftes wat ontvang is. Die gedoopte ontvang vergifnis deur die omhelsing van die beloftes in geloof en word opgeroep om die eis van vergewing na te kom. Vir die gedooptes is hul lewe onverpoosde geloofsvorming, wat ook insluit om die vergewende Christus se beeld te straal in die vergewing van en versoening met ander.

\section{Die doop is ' $n$ doop in Christus se dood en opstanding}

Bespreking van die doop kan nie geïsoleer word van sy breër teologiese konteks van die genade van God, die dood, begrafnis en opstanding van Christus en die werk van die Heilige Gees nie (Cross 1999:177). Die gedooptes is so innig met Christus verbind dat wat met Hom gebeur het in sy dood, opstanding en hemelvaart, ook methulle gebeur. Die doop kan in 1 Korintiërs 6:11 die 'afwassing' genoem word, omdat die doop iemand in verhouding stel met die verlossingsgebeure in Christus, waardeur die ou lewe van sonde weggewas is. Omdat die doop op die verlossingsgebeure gebaseer is, kan die doop self ook 'n afwassing genoem word.

Die doop in Christus of in die Naam van Christus toon aan dat die doop die gelowige aan Christus verbind en onder die seggenskap van Christus bring (Rom 6:3,4). Waar Christus sy seggenskap oor die gelowige laat geld, kan sonde dit nie meer doen nie. Op grond van hul doop in Christus kan die gelowiges weet dat hulle vir die sonde gesterf het (Groenewald 2003:372). Wat openbaringshistories vasgelê is in die een daad van Christus se dood en opstanding (geregtigheid), kom sakramenteel tot hulle in die doop (Immink 2011:178). Dit wil ook prakties in die daaglikse lewe ervaar word. Daarom hoort daar altyd tot die doop 'n 'sodat'. Nadat Paulus die doop gekenmerk het as 'n doop in die dood en begrafnis van Christus (Rom 6:3,4a), volg dan (vers 4b) 'n 'sodat': 'sodat ons 'n nuwe lewe kan lei'. Hierdie nuwe lewe word in verband gebring met Christus se opstanding. Die doop is op die nuwe lewe gerig. Vanuit die doop spoor Christus die dopeling kragtig aan tot 'n nuwe lewe (Voorberg 2007:334). Hier en nou wil die openbaringshistoriese werklikheid in Christus, wat ook die sakramentele werklikheid in die doop is, beleef word. Dit moet ook blyk uit 'n vernuwende en geheiligde lewe.

Die dood van Christus was nie ' $n$ alleenstaande gebeurtenis nie, want daardeur kom die totale ou lewe van die sonde tot ' $n$ einde. Só was die opstanding van Christus ook nie 'n alleenstaande gebeurtenis nie, want daardeur breek die nuwe lewe van die geregtigheid deur. Crowley voer aan: 'In his resurrection he did not return to life. He broke through it into a new state that transcends life as we know it' (1988:291). In Kolossense 2:11,12 is nie sprake daarvan dat die doop daarop dui dat ons met Christus begrawe word nie, maar dat die gedoopte in verhouding gestel word met die weldaad wat uitgedruk word deur die woorde 'saam met Hom begrawe is' (Campbell 1999:283). In die doop is iemand nie net saam met Christus begrawe nie, maar ook saam met Christus opgewek (Crowley 1988:291). Ook hier is die 'opgewek word' in openbaringshistoriese sin bedoel. Die gedagte van opwekking saam met Christus sien op die deurbraak van 'n 
nuwe bestaanswyse in en deur die opstanding van Christus - die aanbreek van die verlossingstyd. Die verlossing wat gegee is en waarna die doop wys, word deur die geloof beleef. Hierdie openbaringshistoriese werklikheid word op sakramentele wyse aan ons geskenk in die doop (Immink 2011:178). Die doop wys terug na die openbaringshistoriese werklikheid in Christus en ontleen daaruit wat die doop is. Die Eerste brief van Petrus, soms beskryf as 'n preek oor die doop, toon in hoofstuk 3:21 aan dat die betekenis van die doop lê in 'n bede tot God om'n nuwe lewe deur die opstanding van Christus (Harrington 2001:74). Dit verteenwoordig 'n ondergang van die ou lewe asook 'n opstanding tot 'n nuwe lewe (Burrows 1999:114) ${ }^{6}$. Colwell beskou dit as: 'Baptism is prospective rather than retrospective; its focus is on the present and future rather than on the past' (1999:218). Wanneer die gemeente leef uit die openbaringsgebeure sal die nuwe lewe van vergewing en versoening in die onderlinge verhoudinge in die gemeente deurwerk (vgl 1 Kor 6:11).

Omdat die doop 'n doop is in Christus se dood, begrafnis en opstanding het die gedoopte deur die geloof deel aan die afsterwing van die sonde en die opstanding van die nuwe lewe. Die doop kan daarom energie gee en effek hê op die gedooptes se besef dat hulle die ou lewe van onvergewensgesindheid en onversoenlikheid afgesterf het. Die nuwe lewe wat die gedoopte lei, is die lewe van Christus. Daarom kan die gedooptes opgeroep word om Christus na te volg deur die naaste te vergewe, met hulle, waar nodig, te versoen en om versoening te bedien.

\section{God se vergifnis en versoening in die doop roep die gedoopte om te vergewe}

In die Nederlandse Geloofsbelydenis bely die reformatoriese kerke in artikel 34 onder andere: 'Hierdie doop is nie alleen nuttig solank die water op ons is en ons dit ontvang nie, maar ook vir ons hele lewe'. Die doop is bevestiging daarvan dat God in Christus vergewe en verhoudinge herstel (versoen) en dat dit geld dwarsdeur die lewe van die gedoopte, wat hierdie beloftes gelowig omhels en toeëien. Een van die belangrikste kontoere van Calvyn se teologie oor die doop is sy beklemtoning dat die doop ' $\mathrm{n}$ hoeksteen is van die Christelike lewe. Calvyn (aangehaal deur Witvliet 1997) verklaar die doop as 'n teken van beide regverdigmaking en heiligmaking:

Justification is the acceptance with which God receives us into his favor as righteous and which consist the remission of sins and the imputation of Christ's righteousness. Christian life is a true turning of our life to God, a turning arises from a pure and earnest fear of him and which consist in the mortification of our flesh and of the old man, and in the vivification of the Spirit. (bl. 154)

6.In 1 Korintiërs 10:1,2 word die Christelike doop vergelyk met die doop van die volk in Moses. Die doop in Moses was' $n$ doop in die wolk en in die see. Positief is die doop as doop in die wolk van beskerming en leiding van God en negatief is die doop as doop in die wolk van beskerming en leiding van God en negatief is die doop as doop in die see van bevryding uit die slawerny van Egipte. Hierdie inhoud van die doop van Moses wys tipologies heen na die doop in Christus. Die positiew wys tipologies heen na die gawe van die Gees as die positiewe aanduiding van die inhoud van die nuwe lewe op grond van die verlossingsgebeure in Christus. Die negatiewe element wys tipologies heen na die bevryding uit die slawerny van die sonde as negatiewe aanduiding van die inhoud van die nuwe lewe op grond van die verlossingsgebeure in Christus.
Gedoopte gelowiges kan met vertroue terugkyk na God se beslissende werk in Christus ten bate van hulle, maar moet ook bewus wees hoe daardie werk behoort voort te duur dwarsdeur die Christelike lewe. Die waarde van die doop lê oop vir die hele lewe, omdat die belofte wat daarin gedra word voortdurend van krag is (Witvliet 1997:156). Old (1992) skryf:

The essence of the Reformed understanding of baptism is the belief that it is a prophetic sign. It is a sign under which the whole of life is to be lived. Our baptism is always with us, constantly unfolding through the whole life. (bl. 179)

Die doop is self ' $n$ handeling van God, maar een met onmiskenbare implikasies vir die lewe van die gedoopte. Omdat die roeping tot vergifnis en versoening 'n belangrike deel uitmaak van die Christelike lewe, behoort die doop daarop 'n effek te hê.

Een van die belangrikste Skrifgedeeltes waarin die doop aan die vergewing van sonde verbind word, is Handelinge 2:38. Petrus lewer sy rede net na die uitstorting van die Heilige Gees en roep sy gehoor op om hulle te bekeer en laat doop in die Naam van Jesus Christus tot vergewing van sondes. Handelinge 2:38 sê dat die doop mag plaasvind op die basis van die openbaring van die persoon van Jesus. Die teks noem dat die doop plaasvind tot vergewing van sonde. Hier is nie sprake van ' $n$ outomatiese of magiese verlening van die vergifnis van sonde deur middel van die doop nie. In die voorsetsel 'tot' word ' $n$ rigting aangedui. Die doop stel die dopeling in relasie tot die vergewing van sonde deurdat in die doop die vergewing van sonde afgebeeld en toegesê word. McIntyre (1996) skei doop en vergewing van sonde: Hy sê:

The best textual evidence supports the presence of $\dot{v} \mu \tilde{\omega} v$ as a modifier of 'sins' in Acts 2:38. New Testament syntax supports this position as well. Concerning the antecedent of $\dot{v} \mu \tilde{\omega} v$, there is no evidence to support the contention that 'forgiveness of sins' modifies the command to be baptized. In other New Testament passages on forgiveness, repentance, and water baptism, it becomes increasingly difficult to find support for the doctrine of baptismal regeneration. Of course this does not dilute the significance of Christian water baptism, for the idea of an unbaptized Christian is simply not entertained in the New Testament. Today, as then, baptism remains a unique testimony of the life-transforming change brought about by the regenerating work of the Holy Spirit in the believer. In water baptism a believer identifies with Jesus Christ in an action that symbolizes the shared experience of death and resurrection with and in Him. (bl. 62)

Teenoor McIntyre beweer Camp (1997) tereg:

Since ह̈ $\kappa \alpha \sigma \tau o \varsigma$ can serve as the antecedent of a plural personal pronoun, Mclntyre's reliance on the rule of concord to separate baptism and forgiveness in Acts 2:38 is misguided. Indeed, virtually all scholars acknowledge some kind of linkage between the two in this verse. Even A. T. Robertson, who vigorously denied that baptism has any role in the forgiveness of sins and whom Mclntyre cites as an authority on the rule of concord, accepted the syntactical relationship between $\varepsilon i \varsigma \ddot{\alpha} \varphi \varepsilon \sigma l v \quad \tau \tilde{\omega} v$ $\dot{\alpha} \mu \alpha \rho \tau \imath \tilde{\omega} v \dot{v} \mu \tilde{\omega} v$ and $\beta \alpha \pi \tau \imath \sigma \theta \dot{\eta} \tau \omega$ in Acts 2:38. (bl. 42)

Bekering word ook in Handelinge 2:38 genoem, want vergifnis van sonde en bekering staan nie los van mekaar nie. Na die 
uitstorting van die Heilige Gees kon die apostels preek dat die nuwe tyd aangebreek het en dat die vergifnis van sonde (as kenmerk daarvan) deur die geloof 'n werklikheid geword het. Die doop dui aan dat God die sondaar vergewe het. Soos die doop die gedoopte in verhouding stel met die vergifnis van sonde, so stel die doop die gedoopte ook in verhouding met die Heilige Gees. Die gedoopte is nou by implikasie afgesonder vir God en moet voortaan 'n nuwe lewenstyl handhaaf wat ooreenkom met die nuwe verlossingstyd. Die Heilige Gees baar lewensvernuwing en getuig só van die feit dat ons gedoop is. Die Heilige Gees maak tot 'n lewenswerklikheid wat in die doop as 'n sakramentele werklikheid tot ons kom (vgl. Tit 3:5). Deur die werking van die Gees, wat uitgaan van die Vader en die Seun, kan God in, met en deur die gedoopte in die samelewing handel om die prosesse van vergifnis en versoening te bevorder. Jones (1995) konstateer:

Forgiveness is not so much a word spoken, and action performed, or a feeling felt as it is an embodied way of life in an ever-deepening friendship with the Triune God and with others ... it ought to be focused on the reconciliation of brokenness, the restoration of communion-with God, with one another, and with the whole Creation. (bl. 5)

Schweitzer (2010:833) haal Webster se definisie van vergewing in sy New Universal Unabridged Dictionary (1983) aan as 'to give up resentment against or the desire to punish, to cancel a debt, to pardon, to absolve or release, and to exonerate'... Watts (2004) vestig ons aandag daarop:

... forgiveness of the bible [sic] is at least as much about a promise for the future. One may infer here, a hope for the future that implies reconciliation or the restoration of relationship and communion with God. I connect this to my understanding of what it means to be baptized insofar as living into the promises of my baptism is a process intertwined with God's promises of forgiveness. (bl. 67)

Watts (2004) maak die gevolgtrekking:

By giving and receiving forgiveness, we extend God's kingdom and make his presence among us a more tangible reality. The practice of forgiveness can, in that sense, be a sacrament of the presence of God. (bl. 68)

Mouton (2001) beskryf versoening verder soos volg:

I nevertheless deliberately suggest 'reconciliation' as an encompassing term for processes of personal, communal, societal and cosmic healing. For the Christian tradition, 'reconciliation' (wholeness, integrity) is the result of God's radical presence in this world, through Jesus Christ and the Spirit. As a rich and authoritative resource - deeply embedded within biblical traditions - it represents a counterfoil for every form of alienation, exclusion and power abuse. 'Reconciliation' (whether between God and human beings, people within and amongst themselves and the earth) originates from God, and finds its ultimate reference in the power of God's healing love and compassion. As such it constitutes the heart of the Christian community's identity, and needs to be continuously reopened, remembered, revitalised, and reclaimed. (bl. 118)

Van die doop gaan 'n appèl uit en in die doop word die gedoopte op die vaste grond van God se beloftes geplaas
(Immink 2011:181). Die gedooptes word nie aan hul eie lot oorgelaat nie, want hulle word in 'n geloofsgemeenskap ingelyf. Daarom ontvang die gedoopte nadere onderrig. Christus beveel immers in Matteus 28:19: 'en leer hulle om alles te onderhou wat Ek julle geleer het'. Dit sluit vergifnis en die bediening van versoening in, want dít veral het Christus met sy dood en opstanding geleer (Voorberg 2007:394).

Die gedooptes word by elke doop herinner dat hulle na die nasies gestuur is om dissipels te maak. Thompsett merk op: 'The request here is not for volunteers. It is, as God's adopted own, to follow Jesus (2004:16).' Daar is nie plek vir blote toeskouers by die bediening van die doop nie. Almal word weer geroep om 'n gemeenskap van diensknegte te wees, om versoening te bedien. Onderrig in die betekenis van die doop is van groot belang. Dit kan by elke bediening van die doop herhaal word, ook by die prediking uit gedeeltes wat oor die doop handel, asook in Bybelstudie, wat die dele uit die Belydenisskrifte insluit. Om aan voorstelle hieroor reg te laat geskied, sal'n volledige wetenskaplike artikel verg.

Die doop is ' $n$ momentele ervaring, maar ook ' $n$ roeping om meer en meer na die beeld van Christus verander te word. Westerfield Tucker (2011) voer aan:

Forgiveness received is also to be forgiveness extended, modeling to the neighbor and to the world the cruciform pattern of life in Christ, and bearing witness to the baptismal ministry of reconciliation. (bl. 11)

Die identifisering van die gedooptes met die vreugde en pyn van die naaste, en hul betrokkenheid in die stryd om die menswaardigheid van die agtergeblewene en die arme, behoort tot die roeping van die gedoopte. Westerfield Tucker (2011) beklemtoon dit só:

The Christian life is thus a baptismal life, lived out in the royal, priestly and prophetic community that is the church wherein the spiritual gifts bestowed for service in the church and the world are exercised. Christian ministries of reconciliation and justice are defined by baptism and belong to the baptismal vocation; the eschatological vision that compels these ministries is rooted in the paschal mystery into which the baptized have been incorporated and continue to participate. (bl. 12)

Die doop is ' $n$ bevestiging daarvan dat God die gedoopte in Christus vergewe en met Hom versoen. Die betekenis en effek van die doop op gedooptes word lewenslank in hul nuwe lewe ontvou. Die doop tot vergifnis van sonde het implikasies vir die nuwe lewe wat met Christus se opstanding deurgebreek het en deur die geloof werklikheid in die gedoopte se lewe geword het. Vergifnis van die naaste en versoening met die naaste is wesentlike aspekte van hierdie nuwe lewe. Deur die werking van die Heilige Gees kan God met die gedoopte handel om die dinamiese werking van vergewing en versoening in die samelewing te bevorder. Die vergifnis wat die gedoopte ontvang, word 'n roeping om vergifnis te soek en versoening te bedien. 


\section{Skriftuurlike vertrekpunte oor doop en versoening in die Suid-Afrikaanse samelewing}

1. God se handeling in die doop verseker die gedoopte se vergifnis en versoening, en so kan die gedooptes agente word van vergewing en versoening in die konteks waarin hulle lewe.

2. Vanuit die sekerheid van die Trinitariese werksaamheid in die doop moet afgelei word dat die gedoopte geplaas is onder die seggenskap en sorg van die Vader, die Seun met sy Koningsheerskappy en die Gees met sy begeleiding in die nuwe lewe. Die feit dat die Drie-enige God werksaam is in die doop roep die gedoopte op tot reaksie waar ook al Christus as die Koning sy heerskappy uitoefen, ook deur vergifnis en versoening.

3. Die monopleuriese en dupleuriese karakter van die verbond stel die gedoopte in ' $n$ intieme verhouding met God. Die gedoopte ontvang vergifnis deur die omhelsing in geloof van die verbondsbeloftes en word opgeroep om die verbondseis van vergewing na te kom.

4. Omdat die doop 'n doop is in Christus se dood, begrafnis en opstanding het die gedoopte deur die geloof deel aan die afsterwing van die sonde en die opstanding van die nuwe lewe. Die doop kan daarom energie gee en effek hê op die gedooptes se besef dat hulle die ou lewe van onvergewensgesindheid en onversoenlikheid afgesterf het en dat hulle opgeroep word om Christus na te volg deur die naaste te vergewe, met hulle waar nodig te versoen en om versoening te bedien.

5. Die doop is ' $n$ bevestiging daarvan dat God die gedoopte in Christus vergewe en met Hom versoen. Die vergifnis wat die gedoopte ontvang, word ' $n$ roeping om vergifnis te soek en versoening te bedien. Deur die werking van die Heilige Gees kan God met die gedoopte handel om die dinamiese handelinge van vergewing en versoening in die samelewing te bevorder.

6. Die doop tot vergifnis van sonde het implikasies vir die nuwe lewe wat met Christus se opstanding deurgebreek en deur die geloof werklikheid in die gedoopte se lewe geword het. Vergifnis van die naaste en versoening met die naaste is wesentlike aspekte van hierdie nuwe lewe.

Aan die hand van hierdie ses prinsipiële uitgangspunte kan in twee opvolgende artikels kwalitatiewe empiriese onderhoude gevoer word. In wisselwerking tussen die empiriese gegewens en prinsipiële gegewens (soos vasgestel in hierdie artikel) kan tot strategieë gekom word om die probleem op te los.

\section{Erkenning \\ Mededingende belange}

Die outeur verklaar hiermee dat hy geen finansiële of persoonlike verbintenis het met enige party wat hom nadelig kon beinvloed in die skryf van hierdie artikel nie.

\section{Literatuurverwysings}

Briggman, A., 2009, 'Measuring Justin's approach to the spirit: Trinitarian conviction and binitarian orientation', Vigiliae christianae 63(2), 107-137. http://dx.doi. org/10.1163/157007208X377274

Burrows, E.W., 1999, 'Baptism in Mark and Luke', in S.E. Porter\& A.R. Cross (eds.), Baptism, the New Testament and the church. Historical and contemporary studies in honour of R.E.O. White, Journal for the study of the New Testament, suppl. ser. 171.

Calvin, J., 1960, Institutes of the Christian Religion, transl. F.L. Battles, Philadelphia, Westminster Press.

Campbell, R.A., 1996, 'Jesus and his baptism', Tyndale Bulletin 47(2),191-214.

Campbell, A., 1999, 'Dying with Christ. The origin of a metaphor', in S.E. Porter \& A.R. Cross (eds.), Baptism, the New Testament and the church. Historical and contemporary studies in honour of R.E.O. White, Journal for the study of the New Testament, suppl. ser. 171.

Camp, A.L., 1997, 'Re-examining the rule of concord in Acts 2:38', Restoration Quarterly 39(1), 37-42.

Colwell, J.E., 1999, 'Baptism, conscience and the resurrection: a reappraisal of 1 Peter $3: 2^{\prime}$, in S.E. Porter \& A.R. Cross (eds.), Baptism, the New Testament and the church. Historical and contemporary studies in honour of R.E.O. White, Journal for the study of the New Testament, suppl. ser. 171.

Cross, A.R., 1999, 'One baptism (Ephesians 4:5): a challenge to the church', in S.E. Porter \& A.R. Cross (eds.), Baptism, the New Testament and the church. Historical and contemporary studies in honour of R.E.O. White, Journal for the study of the New Testament, suppl. ser. 171.

Crowley, J., 1988, 'Baptism as eschatological event', Worship 62(4), 290-298.

De Klerk, B.J., 2011, 'Jesus se gesaghebbende prediking as onderbou van sy opdrag om te gaan doop', In die Skriflig 45(2\&3), 361-384. http://dx.doi.org/10.4102/ ids.v45i2\&3.19

De Villiers, J., 2004, Tweede doop dalk bekyk vir volwassenes, Beeld, 15 Oktober, 2004 , bl. 3

Doriani, D.M., 2003, 'Matthew 28:18-20 and the institution of baptism', in G. Strawbridge (ed.), The case for covenantal infant baptism, pp. 30-48, P \& R Publishing, Phillipsburg, New Jersey.

Evans, W.B., 2005, 'Really exhibited and conferred ... in his appointed time: baptism and the new Reformed sacramentalism', Presbyterion 31(2), 72-88.

Ferguson, S.B., 2009, 'Infant baptism view', in D.F. Wright (ed.), Baptism. Three views, pp. 95-115, Green press initiative, Downers Grove.

Floor, L., 1983, Die heilige doop in die Nuwe Testament, Potchefstroomse Teologiese Publikasies, Potchefstroom.

Goldingay, J., 2001, Isaiah, New international Biblical commentary, Hendrickson Publishers, Peabody.

Groenewald, J., 2003, 'The foundation, value and meaning of baptism in the New Testament', Hervormde Teologiese Studies 59(2), 367-383. http://dx.doi. org/10.4102/hts.v59i2.662

Harrington, D.J., 2001, The church according to the New Testament: What the wisdom and witness of early Christianity teach us today, Sheed \& Ward, Franklin.

Heitink, G., 1999, Practical theology: history, theory, action domains, transl. R. Bruinsma, Eerdmans, Grand Rapids.

Hiebert, D.E., 1992, 'An expository study of Matthew 28:16-20', Bibliotheca Sacra 149(595), 338-354.

Immink, F.G., 2011, Het heilige gebeurt. Praktijk, theologie en traditie van de protestantse kerkdienst, , Uitgeverij Boekencentrum, Zoetermeer.

Jones, G., 1995, Embodying forgiveness: A theological analysis, Grand Rapids, Eerdmans.

Koopman, N., 2005, 'Who am I or whose am I? Christian baptism and identity', Nederduitste Gereformeerde Teologiese Tydskrif 46(3\&4), 448-457.

Krentz, E., 2006, “'Make disciples”: Matthew on evangelism', Currents in Theology and Mission 33(1), 23-41.

Louw, J.P. \& Nida, E.A., 1996, CD-ROM, Greek-English lexicon of the New Testament, based on semantic domains, Libronix Digital Library System 2001, New York.

Mawhinney, A., 1987, 'Baptism, servanthood and sonship', Westminster Theological Journal 49(1), 35-64.

McIntyre, L.B., 1996, 'Baptism and forgiveness in Act 2:38', Bibliotheca Sacra 153, 53-62.

Mouton, E., 2001, 'A Rhetoric of Theological vision on scripture's reorienting power in the liturgy of (social) life', Neotestamentica 35(1-2), 111-127.

Nolland, J., 1999, 'In such a manner it is fitting for us to fulfil all righteousness': Reflections on the place of baptism in the Gospel of Matthew', in S.E. Porter \& A.R. Cross (eds.), Baptism, the New Testament and the church. Historical and contemporary studies in honour of R.E.O. White, Journal for the study of the New Testament, suppl. ser. 171. 
Odendaal, F.F. \& Gouws, R.H. (reds.), 2005, Verklarende Handwoordeboek van die Afrikaanse Taal (HAT), Pearson Education South Africa, Kaapstad, 5 de uitg., bl. 1194.

Old, H.O., 1992, The shaping of Reformed baptismal rite in the Sixteenth century Eerdmans, Grand Rapids.

Osmer, R.R., 2008, Practical Theology - An Introduction, Eerdmans, Grand Rapids.

Pretorius, J., 2003, 'Die groot fokus, die groot gebod en die groot opdrag as sleutels in ' $n$ model vir gemeentebou', PhD-proefskrif, Potchefstroomse Universiteit vir Christelike Hoër Onderwys, Potchefstroom (nou Noordwes-Universiteit).

Ridderbos, H.N., 1987, Matthew. Bible student's commentary, Zondervan, Grand Rapids.

Schweitzer, C.L.S., 2010, "For-giving" and forgiving: Process and practice in pastoral care'. Pastoral Psychology 59, 829-842. http://dx.doi.org/10.1007/s11089-0100293-8

Sparks, K., 2006, 'Gospel as conquest: Mosaic typology in Matthew 28:16-20', Catholic Biblical Quarterly 68(4), 651-663.

Thompsett, F.H., 2004, 'Baptismal living: steadfast covenant of hope', Anglican Theological Review 86(1), 9-18.
Versteeg, J.P., 1983, De doop volgens het Nieuwe Testament, in Van't Spijker, J.P. Rondom de doopvont. Leer en gebruik van de heilige doop in het Nieuwe Testament en in de geschiedenis van de westerse kerk, Uitgeverij De Groot Goudriaan, Kampen.

Voorberg, P.L., 2007, Doop en kerk. De erkenning, door kerkelijke gemeenschappen, van de elders bediende doop, Uitgeverij Groen, Heerenveen.

Vorster, J.M., 2011, Menswaardigheid, versoening en vergiffenis, Potchefstroomse Teologiese Publikasies, Potchefstroom.

Waddell, P., 2009, 'Ordained by Christ in his church: Jesus and baptism', Theology $112(866), 83-91$

Watts, F., 2004, 'Christian theology', in F. Watts \& L. Gulliford (eds.), Forgiveness in context: Theology and psychology in creative dialogue, pp. 50-68, T. \& T. Clark, New York.

Westerfield Tucker, K.B., 2011, Presidential address. Societas Liturgica congress, Reims, France, 11 August 2011.

Witvliet, J.D., 1997, 'Baptism as a sacrament of reconciliation in the thought of John Calvin', Studia Liturgica 27(2), 152-165.

Wright, D.F., 1989, 'The meaning of reference of "one baptism for the remission of sins" in the Niceno-Constantinopolitan Creed', Studio Patristica 19, 281-285. 